\title{
Survival and life strategy of the foraminiferan Globobulimina turgida through nitrate storage and denitrification
}

\author{
Elisa Piña-Ochoa ${ }^{1, * *}$, Karoliina A. Koho ${ }^{2, *, * *}$, Emmanuelle Geslin $^{3,4}$, \\ Nils Risgaard-Petersen ${ }^{1}$ \\ ${ }^{1}$ Center for Geomicrobiology, Institute of Biological Sciences, Aarhus University, 8000 Aarhus C, Denmark \\ ${ }^{2}$ Utrecht University, Faculty of Geosciences, Aardwetenschappen building, 3584 CD Utrecht, The Netherlands \\ ${ }^{3}$ Laboratory of Recent and Fossil Bio-Indicators, Angers University, 49045 Angers Cedex, France \\ ${ }^{4}$ Laboratory of Marine Bio-Indicators (LEBIM), 85350 Ile d'Yeu, France
}

\begin{abstract}
In a laboratory experiment, we examined the prolonged survival and behaviour of the benthic foraminiferan Globobulimina turgida under 3 simulated natural conditions: oxygenated with added nitrate, anoxic with added nitrate, and anoxic. The survival rates, adenosine triphosphate (ATP) reserve and intracellular nitrate pool of G. turgida were measured periodically under these conditions. Furthermore, to evaluate the efficiency and energy yield of the respiration system, denitrification rates of individual specimens were quantified using the acetylene inhibition and $\mathrm{N}_{2} \mathrm{O}$ microsensor technique at the start of the experiment. Our results demonstrate that the long-term (56 d) survival rate (64\%) and ATP concentrations of G. turgida were not significantly different in oxygenated and anoxic, nitrate-containing conditions (Mann-Whitney test, $\mathrm{p}>0.05$ ). Thus, G. turgida can survive prolonged anoxia ( $3 \mathrm{mo}$ ) as long as nitrate is available to sustain its respiration. However, it remains unsure whether growth or reproduction can take place under anoxia. Short-term (21 to 35 d) survival rates were lower in nitrate-free, anoxic conditions ( $22 \%$ recovered alive compared to 62 to $82 \%$ in nitrate-oxic or nitrate-anoxic conditions), but foraminifera were observed to survive up to $56 \mathrm{~d}$ if respiring from their intra-cellular nitrate pool only. The foraminiferal nitrate pool appears very dynamic, as wide ranges of concentrations were measured in living specimens (0 to $463 \mathrm{mM}$ ind. ${ }^{-1}$ ). We postulate that the scatter in the nitrate pool measurements highlights the ability of the foraminifera to actively collect and respire on nitrate, depending on individuals' history of exposure to oxygen and nitrate.
\end{abstract}

KEY WORDS: Benthic foraminifera $\cdot$ Denitrification $\cdot$ Intracellular nitrate $\cdot$ ATP $\cdot$ Anoxia

\section{INTRODUCTION}

Foraminifera are unicellular eukaryotic organisms that are abundantly present in the marine realm. They are amongst the most successful benthic organisms and are found in a wide range of environments from shallow brackish waters to the deepest parts of the ocean (van der Zwaan et al. 1999). Many species thrive below the oxic-anoxic interface (e.g. Jorissen et al. 1995, 2007, Fontanier et al. 2003, Koho et al. 2008a), which implies that they have either a fermentative or a respiratory metabolism based on electron acceptors other than oxygen. Recently, it has been demonstrated that many benthic foraminiferal species appear to be facultative anaerobes, allowing them to use both oxygen and nitrate for respiration (Risgaard-Petersen et al. 2006, Høgslund et al. 2008, Piña-Ochoa et al. 2010). These species seem to respire nitrate through denitrification (i.e. the dissimilatory reduction of nitrate to gaseous N). Foraminiferal denitrification is sustained through an intracellular nitrate pool (RisgaardPetersen et al. 2006). Thus, foraminifera actively collect and store nitrate in their cell, enabling them to sustain respiratory activities even when the desired electron acceptors (oxygen, nitrate) are absent from the environment. This versatile metabolic capacity of 
these organisms may be one of the reasons for their successful colonisation of diverse marine environments. However, little is known about the metabolic activity of foraminifera in anoxic environments (Bernhard 1993, Bernhard \& Alve 1996), and it remains unknown whether energy gained from nitrate respiration is enough to sustain growth, reproduction and completion of their lifecycle. Data from Bernhard \& Reimers (1991) and Moodley et al. $(1997,1998)$ suggest that foraminifera, typically found in oxygen-depleted environments, cannot survive prolonged anoxia. Therefore, questions arise regarding foraminiferal survival mechanisms and how they can gain energy to sustain their metabolic activities under such apparently adverse conditions.

This study was designed to assess the survival and ATP activity of the denitrifying foraminiferan Globobulimina turgida and its use and development of the intracellular nitrate pool under various (prolonged) oxygen/nitrate conditions. Furthermore, we also addressed whether G. turgida survives anoxia by being dormant versus active. Throughout the experiment, the number of living specimens was monitored, and their internal nitrate pool and cellular energy (adenosine triphosphate, ATP) reserves were measured under such conditions to establish foraminiferal survival and activity. Knowledge on the respiratory strategy of individual foraminiferal species will explain the survival strategy of foraminifera occurring in seasonally or permanently oxygen-depleted environments and also add to our understanding of foraminiferal microhabitats, an important parameter in foraminiferal pollution monitoring (e.g. Irabien et al. 2008, Mojtahid et al. 2008) and in palaeoenvironmental reconstructions based on foraminiferal species distributions (e.g. van der Zwaan et al. 1999, Jorissen et al. 2007).

\section{MATERIALS AND METHODS}

Study site and sediment processing. Sediment was collected from the deep basin (Alsbäck, depth: $119 \mathrm{~m}$; $58^{\circ} 19.4^{\prime} \mathrm{N}_{i} 11^{\circ} 32.7^{\prime} \mathrm{E}$ ) of the Gullmar Fjord, Sweden, in April 2008. The deep fjord has a relatively stable bottom water temperature $\left(6^{\circ} \mathrm{C}\right)$ and salinity $(\sim 34$; Nordberg et al. 2000). The bottom water concentrations of oxygen and nitrate were $160 \mathrm{mM}$ and $15 \mathrm{mM}$, respectively. Sediment at the study site is organic rich ( 3 wt\%, Filipsson et al. 2004), muddy with a porosity of 0.75 to $0.85(\mathrm{v} / \mathrm{v})$ and molar $\mathrm{C} / \mathrm{N}$ ratio of 10 (Engström et al. 2005). An Olausson-grab designed to collect intact, cubic samples of the soft bottom seafloor was used onboard RV 'Oscar von Sydow' to collect the sediment. The cubic samples were subsequently subsampled for the top 10 to $15 \mathrm{~cm}$ of sediment using plas- tic tubes of various dimensions (on average $\varnothing 6 \mathrm{~cm}$ ). Intact cores were then transported to Utrecht University in cool boxes. In Utrecht, the cores were placed in an aquarium $\left(10^{\circ} \mathrm{C}\right)$ that was filled with in situ seawater.

In April 2009, the top $2 \mathrm{~cm}$ of the sediment cores were sliced (at $1 \mathrm{~cm}$ intervals) and sieved over $150 \mu \mathrm{m}$ mesh. The sieving was carried out using in situ seawater. Globobulimina spp. normally occur relatively deep in the sediment (e.g. Jorissen et al. 1995, Kitazato et al. 2000, Fontanier et al. 2003, Koho et al. 2008a); however, in Gullmar Fjord this species is commonly found in the upper 1.5 to $2 \mathrm{~cm}$ of the sediment (Risgaard-Petersen et al. 2006), most likely due to the relatively shallow redox zonation in the sediment. The sieved sediment was transported to Aarhus University in a cool box where the experiment was set up.

Identification and collection of living Globobulimina turgida. Identification of living foraminiferans was carried out using non-terminal methods. Specimens assumed to be alive in the sieve residue (bearing a good colouration, cytoplasm well-defined, sediment gathered around the aperture) were gently picked out and placed into a Petri dish containing artificial seawater (ASW, Red Sea Salt; salinity 34 to 35) and a thin layer of fine-grained sediment $\left(<38 \mu m_{i}\right.$ sediment sieved from the same experimental cores). ASW was used throughout the experiment, so nitrate concentrations could be controlled. Only the specimens that moved (within $\sim 16 \mathrm{~h}$ ) and thus produced a burrow or a trace on the sediment surface were considered living and used in the experiment.

Experimental design and set-up. Three aquaria (Fig. 1) were set up with distinctive chemical conditions, although all aquaria were kept at constant salinity (35) and temperature $\left(15^{\circ} \mathrm{C}\right)$. Aquarium 1 (Oxic+Nitrate_AQ) contained well oxygenated ASW amended with $50 \mu \mathrm{M} \mathrm{NO}_{3}{ }^{-}$. High oxygen concentrations were sustained by vigorous bubbling of seawater with compressed air. The oxygen concentrations were stable throughout the experiment, measuring approximately $200 \mu \mathrm{mol}$. Aquarium 2 (Anoxic+ Nitrate AQ) contained anoxic ASW with added $50 \mathrm{\mu M} \mathrm{NO}_{3}{ }^{-}$. Aquarium 3 (Anoxic_AQ) contained anoxic nitrate-free ASW. The low oxygen conditions in Anoxic+ Nitrate_AQ and Anoxic_AQ were maintained by a steady introduction of $\mathrm{N}_{2}$ gas mixed with $0.04 \% \mathrm{CO}_{2}$ (to keep the $\mathrm{pH}$ stable) into the overlying water column. Oxygen concentrations were monitored with permanently installed Clark-type oxygen microelectrodes with a tip diameter of $125 \mu \mathrm{m}$ (Revsbech 1989). The oxygen concentrations in both anoxic aquariums remained below the detection limit $(0.5 \mu \mathrm{M})$ of the sensor throughout the incubation period. The sensors were 2-point calibrated in air-saturated ASW (salinity 35, 

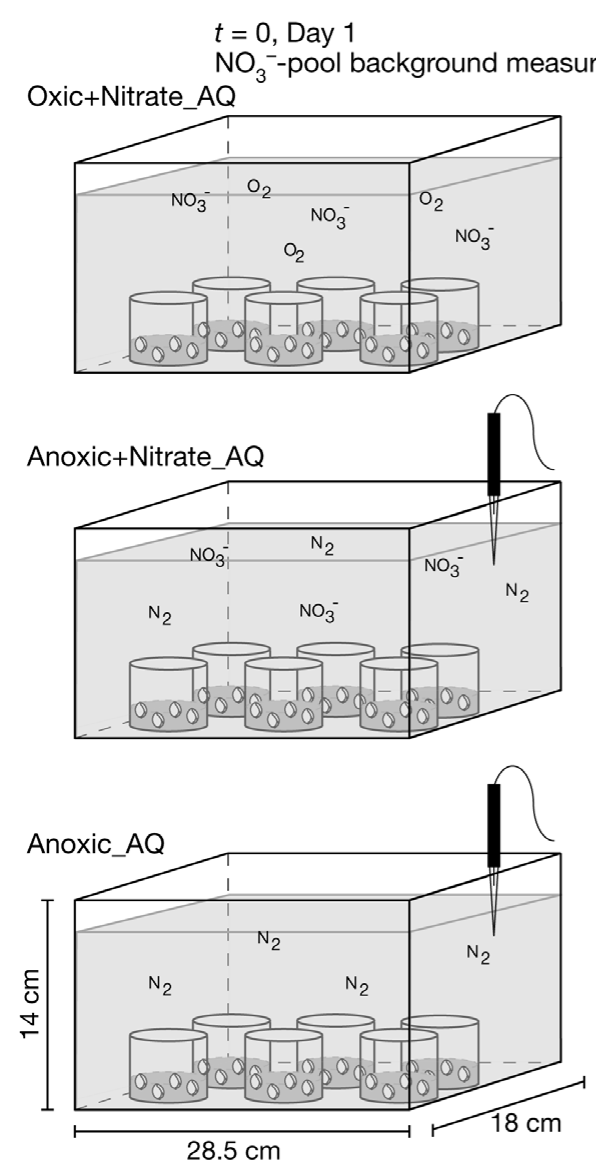

$t=1$, Day ents
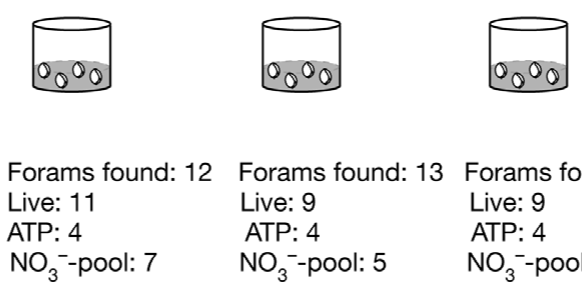

$t=3$, Day 35

$t=4$, Day 56

$t=5$, Day 84

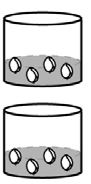

$\underset{000}{0.00}$
Forams found: 14

Live: 9

ATP: 3

$\mathrm{NO}_{3}^{-}$-pool: 6
Forams found: 26

Live: 10

ATP: 4

$\mathrm{NO}_{3}{ }^{-}$-pool: 6

$\begin{array}{ll}\text { Forams found: } 13 & \text { Forams found: } 11 \\ \text { Live: } 9 & \text { Live: } 9 \\ \text { ATP: } 4 & \text { ATP: } 4 \\ \mathrm{NO}_{3}^{-} \text {-pool: } 5 & \mathrm{NO}_{3}^{-} \text {-pool: } 5\end{array}$

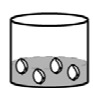

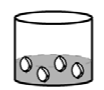

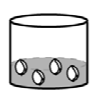

Forams found: 11

\section{Live: 9}

ATP: 4

$\mathrm{NO}_{3}^{-}$-pool: 5

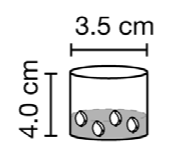

Forams found: 12

Live: 9

ATP: 4

$\mathrm{NO}_{3}^{-}$-pool: 5

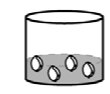

Live: 8

ATP: 4

$\mathrm{NO}_{3}^{-}$-pool: 4

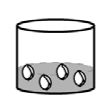

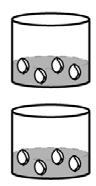

Forams found: 24

Forams

ATP: 6 $\mathrm{NO}_{3}{ }^{-}$-pool: 5

Fig. 1. Experimental set up and time line. Numbers of Globobulimina turgida recovered (Forams found) and identified live (Live; based on FDA staining). The number of living specimens measured for ATP and the nitrate pool at each sampling time is indicated. Artificial seawater (ASW) was used to set up all aquaria, allowing the manipulation of nitrate levels in each aquarium. Nitrate was added to the oxic aquarium to create natural conditions; natural nitrification under oxic conditions could not have been excluded from the set up. At $t=0$ (Day 1), background measurements of the intracellular nitrate pool were made. In total, 8 specimens were measured

$15^{\circ} \mathrm{C}$ ) and anoxic alkaline ascorbate. All 3 aquaria were sealed to prevent any evaporation and to maintain constant gas concentration. The nitrate content in all aquaria was monitored periodically and ranged between 30 and $60 \mu \mathrm{M}$ in Oxic+Nitrate_AQ and Anoxic+ Nitrate_AQ. During the experiment, nitrate was added to the Oxic+Nitrate_AQ and Anoxic+Nitrate_AQ to sustain the desired high nitrate concentrations.

Six small vials (each $30 \mathrm{ml}$ ), all containing 14 living Globobulimina turgida and a thin layer of fine-grain sieved sediment $(<38 \mu \mathrm{m})$, were placed in each aquarium. Fine-grained sediment slurry $(4 \mathrm{ml})$ was transferred with a syringe into each vial to create more 'natural' conditions for the foraminifera. Following compaction, the sediment layer was $\sim 1 \mathrm{ml}$ in volume.

The experiment ran for 3 mo. All aquaria were sampled at $7 \mathrm{~d}(t=1), 21 \mathrm{~d}(t=2), 35 \mathrm{~d}(t=3)$ and $56 \mathrm{~d}(t=$ 4). In addition, Oxic+Nitrate_AQ and Anoxic+Nitrate_ $\mathrm{AQ}$ were sampled at $84 \mathrm{~d}(t=5)$. Furthermore, back- ground measurements of the intracellular nitrate pool were carried out on Day $1(t=0)$. At each sampling time, a vial (or 2 if only a few living foraminifera were identified at the time: at $t=3$ and 4 in Anoxic_AQ; at $t=$ 5 in Oxic+Nitrate_AQ and Anoxic+Nitrate_AQ) was taken from each aquarium. The majority (79 to $100 \%$ ) of foraminifera were found, checked for viability using the fluorescein diacetate (FDA) technique (see next section) and counted. The living specimens were measured for their intracellular nitrate pool (see section 'Internal nitrate content in foraminifera') or cellular ATP content (see section 'ATP extraction and measurements'). In addition, at sample times $t=3$ and 5, 8 dead specimens were also measured for intracellular nitrate content. Following every sampling, some fresh ( 1 ml) fine-grained sediment was added to the surface of the sediment in the vials to provide a food source for the foraminifera. In addition, at the start of the experiment $(t=0)$ the denitrification rate of Globobulimina turgida 
was measured using a microsensor technique (see section 'Denitrification measurements').

Identification of living individuals during the experiment: FDA staining. Identification of living foraminifera based on movement is time consuming, which is not ideal while processing several incubation chambers simultaneously. In addition, time-consuming methods may bias the experimental results. Therefore, epifluorescence microscopy was used to distinguish living from dead specimens. The fluorescence technique is a powerful, reliable and quick method to identify living individuals in experimental setups (Bernhard et al. 1995), particularly under anoxic conditions. Incubation in fluorogenic probes causes live specimens to become fluorescent, while dead specimens will not easily be detected. The fluorogenic probe used in this experiment was FDA, which was diluted in a dimethyl sulphoxide solution and ASW in order to obtain a final solution of $100 \mu \mathrm{M}$ FDA. All samples were incubated in ASW-FDA solution for 3 to $4 \mathrm{~h}$. Foraminifera were then picked out and placed in ASW with no FDA. Each specimen was checked individually for fluorescence using an Axiovert 200M Apotome epifluorescence microscope (Carl Zeiss).

Reliability of the FDA staining: To investigate the possible FDA staining of dead foraminifera, 10 living Globobulimina turgida (identified by movement) were either heat killed $\left(2 \mathrm{~h}\right.$ at $45^{\circ} \mathrm{C}$ ) or placed for a short while in $70 \%$ ethanol. Specimens killed in ethanol were placed back in natural seawater for $2 \mathrm{~h}$ to allow any bacterial recolonisation. Both living and dead specimens were then incubated in FDA-ASW for 3 to $4 \mathrm{~h}$. After the incubation, the specimens were placed in fresh ASW (no FDA), and the intensity of fluorescence in specimens was visually examined by epifluorescence microscopy. Live specimens produced a very intense bright glow, the glow being brightest in the outermost chamber of foraminifera. In contrast, the dead foraminifera produced no glow, or a very dull homogenous glow often absent in the outermost chamber of foraminifera. The dull glow in the dead foraminifera was most likely produced by bacteria.

FDA test on the internal nitrate content in Globobulimina turgida: Prior to the experiment, the possible influence of FDA staining on the internal nitrate pool was measured in 10 living specimens of G. turgida (5 stained with FDA and 5 non-stained; the non-stained specimens were identified as alive according to movement within ca. $16 \mathrm{~h}$. The internal nitrate pool measurements in both stained and non-stained foraminifera were comparable and within the values previously reported for G. turgida (Risgaard-Petersen et al. 2006), ranging between 2094 and 5153 pmol cell $^{-1}$ for nonstained and between 4564 and 9119 pmol cell $^{-1}$ for stained specimens. Therefore, FDA probing was applied without further considerations.
Internal nitrate content in foraminifera. Foraminifera were gently cleaned of sediment with a brush and rinsed in nitrate-free ASW. The specimens were then transferred to PCR tubes and analysed for nitrate content using the $\mathrm{VCl}_{3}$ reduction method (Braman \& Hendrix 1989) on a chemiluminescence detector (Model CLD 86, Eco Physics AG) as described by RisgaardPetersen et al. (2006) and Høgslund et al. (2008), with modification by Piña-Ochoa et al. (2010). The analysis was carried out immediately when possible; alternatively, specimens were stored at $-20^{\circ} \mathrm{C}$ until analysis within $1 \mathrm{wk}$ of sampling.

ATP extraction and measurements. ATP, a basic chemical fuel of living cells, is produced during oxidation of food molecules and powers most of the cell's activities (Alberts et al. 1998) and thus served here as an indication of metabolism and activity of foraminifera in the various experimental conditions. ATP extractions and measurements followed protocols described by Linke (1992) and Witzel (1979), respectively. ATP was extracted from individual specimens of Globobulimina turgida. Each foraminiferan was transferred into a test tube and rinsed with $2 \mathrm{ml}$ of boiling $0.02 \mathrm{M}$ Tris buffer ( $\mathrm{pH}$ 7.8). Tubes were held in an Erlenmeyer flask with boiling water for $30 \mathrm{~s}$. To optimise the extraction efficiency, the tests of the foraminifera were crushed with a glass rod. The sample extracts were stored at $-20^{\circ} \mathrm{C}$ until later analysis. The real dilution of the samples was determined by weighing the test tubes with and without the extractions. The measurements were carried out using a Berthold detection system FB12 Luminometer.

Denitrification measurements. The viability of Globobulimina turgida used for denitrification measurements was based on movement of specimens (within ca. $16 \mathrm{~h}$ ), and the measurements were carried out immediately after the harvest of live specimens. Foraminiferal nitrate respiration rates were measured using the acetylene inhibition technique. Acetylene blocks the reduction of $\mathrm{N}_{2} \mathrm{O}$ to $\mathrm{N}_{2}$, thus allowing the measurement of $\mathrm{N}_{2} \mathrm{O}$ as the end product of denitrification (Smith et al. 1978). $\mathrm{N}_{2} \mathrm{O}$ production was measured with an $\mathrm{N}_{2} \mathrm{O}$ microsensor (Andersen et al. 2001), as described by Risgaard-Petersen et al. (2006), Høgslund et al. (2008) and Piña-Ochoa et al. (2010).

\section{RESULTS AND DISCUSSION}

\section{Foraminiferal response to different treatments: survival and cellular ATP reserve}

For the first $3 \mathrm{wk}$, the numbers of living Globobulimina turgida were relatively similar in all aquaria, ranging from 70 to $92 \%$ (Fig. 2). However, over the 

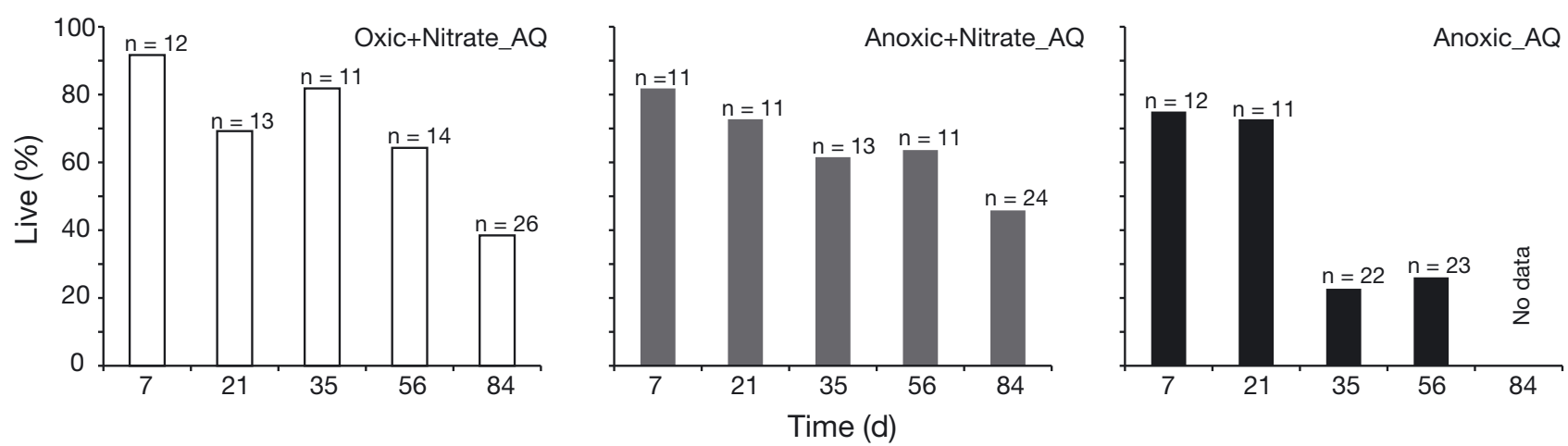

Fig. 2. Globobulimina turgida. Fraction of live foraminifera (\%) at each sampling time. Note that Anoxic_AQ was not sampled at $84 \mathrm{~d}$

longer term, the survival rates were higher in the aquaria where either oxygen and nitrate (Oxic+ Nitrate_AQ), or nitrate (Anoxic+Nitrate_AQ) was readily available in the surrounding environment to sustain foraminiferal respiration. In Anoxic_AQ, where foraminiferal respiration was restricted to the intracellular nitrate pool, only $\sim 25 \%$ of G. turgida were found alive after an incubation period of 35 ( $\mathrm{n}=$ $22)$ and $56 \mathrm{~d}(\mathrm{n}=23)$. Death of specimens in Anoxic AQ most likely resulted from declining intracellular nitrate concentrations, which at the end were insufficient to sustain cellular respiration. In contrast, in Oxic+Nitrate_AQ at $35 \mathrm{~d}(56 \mathrm{~d}),>80 \%$ (>60\%) of foraminifera were still alive. Similarly, in Anoxic+ Nitrate_AQ at both sample times, $>60 \%$ of foraminifera were still alive. Thus, the long-term survival in Oxic+Nitrate_AQ and Anoxic+Nitrate_AQ appeared similar, or even somewhat higher in Anoxic+ Nitrate_AQ. At the end of the experiment, after $84 \mathrm{~d}$, $38 \%(\mathrm{n}=26)$ of foraminifera were still alive in Oxic+Nitrate_AQ and $46 \%(\mathrm{n}=24)$ were alive in Anoxic+Nitrate_AQ. These results indicate that $G$. turgida does not need oxygen to sustain metabolic activities, but can maintain long-term nitrate respiration. However, as no reproduction was observed during the experiment (always $\leq 14$ specimens found in each vial, Fig. 1), it remains unsure what the optimal conditions are for reproduction to take place.

Large variations were measured in the ATP content within each treatment at various sampling times (Fig. 3, Table 1). The highest ATP concentration (243.5 ng $\mathrm{g}^{-1}$ ) was measured in Anoxic+Nitrate_AQ at $t=3$ (after $35 \mathrm{~d}$ ) followed by $224.1 \mathrm{ng} \mathrm{g}^{-1}$ in the Oxic+ Nitrate_AQ at $t=1$, and the lowest (below detection limit) in Oxic+Nitrate_AQ at $t=5$ (after $84 \mathrm{~d}$ ). ATP concentrations varied significantly through time only in Oxic+Nitrate_AQ (Table 2), and a general decrease was observed with a longer incubation period (Fig. 3). In Anoxic+Nitrate_AQ and Anoxic_AQ, no statistically significant variations were observed, and no trend was

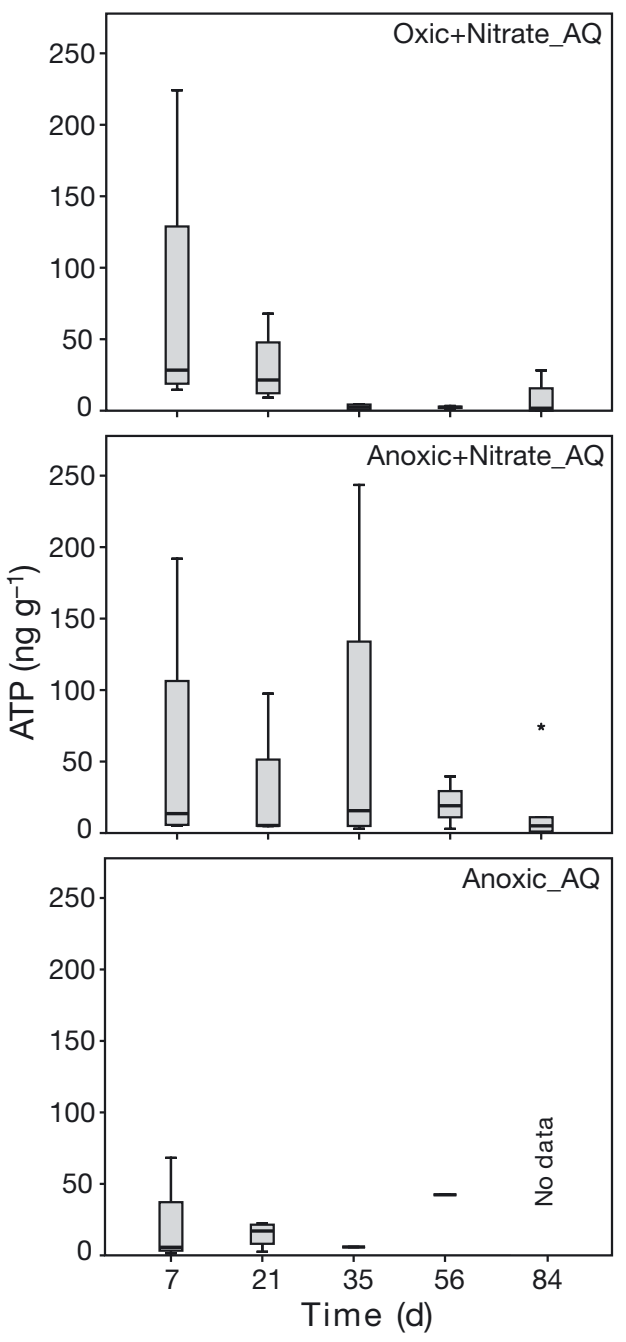

Fig. 3. Globobulimina turgida. Median ATP content of foraminiferans versus time for each aquarium. No ATP was measured at $t=0$. The box limits are set at the 25th and 75th percentiles. The whiskers extend to 1.5 times the height of the box, thus representing approximately a $95 \%$ range. If no case/row has a value in the whisker range, the whiskers are defined by the minimum or maximum values. An outlier is shown with an asterisk 
observed in the median ATP content through time (Fig. 3), implying that foraminifera were metabolically equally active in both setups. Further, the Anoxic+

Table 1. Globobulimina turgida. Summary of the foraminiferal ATP data for each sampling time and aquarium; minimum (min.), maximum (max.), median (mdn), average (ave.) and number of individuals measured (n). Note no data for Anoxic_AQ at $t=5$; bd: below detection limit; na: not applicable

\begin{tabular}{|c|c|c|c|c|c|}
\hline \multirow{2}{*}{$\begin{array}{l}\text { Treatment/ } \\
\text { time }\end{array}$} & \multicolumn{5}{|c|}{ ATP $\left(\mathrm{ng} \mathrm{g}^{-1}\right)$} \\
\hline & $\mathrm{n}$ & Min. & Max. & Mdn & Ave \\
\hline \multicolumn{6}{|c|}{ Oxic+Nitrate_AQ } \\
\hline $1(7 \mathrm{~d})$ & 4 & 14.6 & 224.1 & 28.4 & 68.8 \\
\hline $2(21 \mathrm{~d})$ & 4 & 9.1 & 67.6 & 21.5 & 30.0 \\
\hline $3(35 d)$ & 4 & 0.6 & 4.5 & 2.5 & 2.5 \\
\hline $4(56 \mathrm{~d})$ & 3 & 1.3 & 3.3 & 2.4 & 2.3 \\
\hline $5(84 \mathrm{~d})$ & 4 & $0(\mathrm{bd})$ & 28.2 & 1.7 & 7.8 \\
\hline \multicolumn{6}{|c|}{ Anoxic+Nitrate_AQ } \\
\hline $1(7 \mathrm{~d})$ & 4 & 5.1 & 191.8 & 13.6 & 56.0 \\
\hline $2(21 \mathrm{~d})$ & 3 & 4.8 & 97.5 & 5.3 & 35.9 \\
\hline $3(35 d)$ & 4 & 3.0 & 243.5 & 15.6 & 69.4 \\
\hline $4(56 \mathrm{~d})$ & 3 & 2.9 & 39.6 & 19.1 & 20.5 \\
\hline $5(84 \mathrm{~d})$ & 6 & 0.2 & 74.3 & 5.0 & 11.7 \\
\hline \multicolumn{6}{|l|}{ Anoxic_AQ } \\
\hline $1(7 \mathrm{~d})$ & 4 & 1.5 & 68.2 & 5.6 & 20.2 \\
\hline $2(21 \mathrm{~d})$ & 4 & 2.5 & 22.5 & 17.1 & 14.8 \\
\hline $3(35 d)$ & 1 & na & na & 5.9 & 5.9 \\
\hline $4(56 \mathrm{~d})$ & 1 & na & na & 42.4 & 42.4 \\
\hline
\end{tabular}

Table 2. Outcome of the Kruskal-Wallis test based on the foraminiferal ATP data from each aquarium

\begin{tabular}{|lrc|}
\hline Treatment & $H(\mathrm{df})$ & $\mathrm{p}$ \\
\hline Oxic+Nitrate_AQ & $10.47(4)$ & 0.033 \\
Anoxic+Nitrate_AQ & $2.30(4)$ & 0.682 \\
Anoxic_AQ & $1.90(3)$ & 0.603 \\
\hline
\end{tabular}

Table 3. Outcome of the Mann-Whitney test (2-tailed p), comparing the foraminiferal ATP data from anoxic, $\mathrm{N}_{2}$-flushed aquaria (Anoxic+Nitrate_AQ, Anoxic_AQ) to the aerated control aquarium (Oxic+Nitrate_AQ)

\begin{tabular}{|lccccc|}
\hline Mann-Whitney test & \multicolumn{5}{c|}{ Oxic+Nitrate_AQ } \\
& $(7 \mathrm{~d})$ & $(21 \mathrm{~d})$ & $(35 \mathrm{~d})$ & $(56 \mathrm{~d})$ & $(84 \mathrm{~d})$ \\
\hline Anoxic+Nitrate_AQ; & $0.248 ;$ & & & \\
Anoxic_AQ (7 d) & 0.149 & & & \\
Anoxic+Nitrate_AQ; & $0.480 ;$ & & \\
Anoxic_AQ (21 d) & 0.386 & $0.083 ;$ & \\
Anoxic+Nitrate_AQ; & & 0.157 & & \\
Anoxic_AQ (35 d) & & & $0.127 ;$ & \\
Anoxic+Nitrate_AQ; & & & 0.180 & \\
Anoxic_AQ (56 d) & & & & 0.394 \\
Anoxic+Nitrate_AQ & & & & \\
& & & & & \\
\end{tabular}

Nitrate_AQ and Anoxic_AQ were statistically not different from the aerated control aquarium (Oxic+ Nitrate_AQ) at any sample moment (Table 3, MannWhitney test, $\mathrm{p}$ always $>0.05$ ). Therefore, it seems that the ATP content does not differ between denitrifying and aerobically respiring Globobulimina turgida, and that $G$. turgida is 'equally' active in both environments and does not display potential dormancy under anoxic conditions.

In previous studies, the ATP content of foraminifera experiencing prolonged anoxia $\left(\mathrm{N}_{2}\right.$-purged) versus aerobic conditions has been reported as similar (Bernhard 1993) or lower in the former (Bernhard \& Alve 1996). The contradictory evidence may be related to interspecies differences, and differences in their ultrastructure (Bernhard \& Alve 1996). A decrease in ATP content in foraminifera has also been previously related to low food supply (Graf \& Linke 1992, Linke 1992), as the ATP concentrations in deep-sea benthic foraminifera were observed to increase drastically following phytoplankton deposition. In our experiment, food supply may have played a role at least in the Oxic+Nitrate_AQ where the median ATP concentrations were seen to decline with time (Fig. 3). As the Oxic+Nitrate_AQ was continuously aerated, sedimentary organic matter in it would have been more rapidly oxidised (due to the higher energy yield of oxygen than nitrate, e.g. Bender \& Heggie 1984) than in the anoxic aquaria, thus leading to lower food supply. The low food content in the Oxic+Nitrate_AQ could also explain the somewhat higher long-term survival rates in the Anoxic+Nitrate_AQ (Fig. 2). This observation is also supported by laboratory observations of Koho et al. (2008b), who reported declining foraminiferal standing stocks in non-fed control cores (especially the 63 to $150 \mu \mathrm{m}$ fraction) after a $56 \mathrm{~d}$ incubation period. Further, our ATP measurements of Anoxic+Nitrate_AQ and Anoxic_AQ may have been compromised, as the isolation of foraminifera for the ATP measurements was performed under oxygenated conditions that could have led to a sudden increase in metabolic activity. However, this appears unlikely, as following reaeration of a previously anoxic experimental setting, the ATP concentration in foraminifera remained unchanged (J. Berhard \& E. Alve unpubl. data, as cited by Bernhard \& Alve 1996).

\section{Nitrate storage in foraminifera}

Nine out of 9 dead Globobulimina turgida specimens measured for intracellular nitrate did not contain any nitrate. However, extraction of relatively high amounts $(>250 \mathrm{mM})$ of intracellular nitrate from living $G$. turgida was possible in all 3 treatments (Fig. 4). Nitrate 


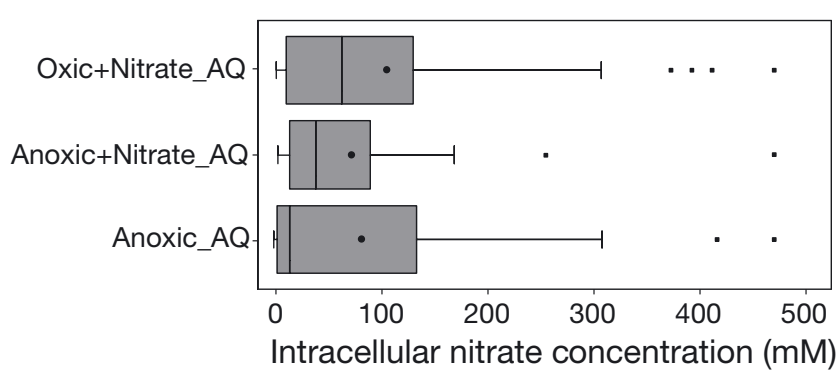

Fig. 4. Globobulimina turgida. Intracellular nitrate concentration in live specimens sampled in 3 different aquaria. Boxes include 25 to $75 \%$ of overall data, medians are indicated by the centre line of the boxes, black circles are mean values and whiskers comprise the whole range of data. Outliers are shown as small black squares

was measured in 28 out of 29, 24 out of 24 and 19 out of 21 living specimens from Oxic+Nitrate_AQ, Anoxic+ Nitrate_AQ and Anoxic_AQ, respectively. Nitrate concentration among $G$. turgida individuals ranged from 0 to $463 \mathrm{mM}$, and these concentrations corresponded to an average concentration in all treatments of about $93 \mathrm{mM}-104 \pm 126$ (SD), $72 \pm 93,97 \pm 128$ in Oxic+ Nitrate_AQ, Anoxic+Nitrate_AQ and Anoxic_AQ, respectively. The measured intracellular nitrate concentrations are well within the range of values reported for Globobulimina by Risgaard-Petersen et al. (2006) and Glud et al. (2009). Similar intracellular nitrate concentrations (up to $500 \mathrm{mM}$ ) have also been observed in white sulphur bacteria belonging to the family Beggiatoaceae (Beggiatoa, Thioploca and Thiomargarita; Fossing et al. 1995, McHatton et al. 1996, Schulz et al. 1999, Sayama 2001), corresponding to 4000 -fold higher concentration levels than in the ambient environment. These findings suggest that nitrate accumulation is a universal property of vacuolated, filamentous sulphur bacteria, as well as Foraminifera and Gromiida (Piña-Ochoa et al. 2010).

High variability was measured in the intracellular nitrate pool within each treatment (Figs. 4 \& 5); the coefficient of variation was 120, 129 and $132 \%$ for Oxic+ Nitrate_AQ, Anoxic+Nitrate_AQ and Anoxic_AQ, respectively. To explain some of the data scatter, a size-dependent relationship was suggested by Glud et al. (2009) for the intracellular nitrate store in Globobulimina affinis. In our study (data not shown), the variability in the size of intracellular nitrate store was not related to the size of the foraminifera, and no relationship was observed between these parameters. In fact, some of the highest intracellular nitrate pools were measured in relatively small specimens. Instead, we postulate that the scatter in the measurements highlights the active nature of the foraminifera to collect and respire on nitrate, depending on individuals' his- tory of exposure to oxygen and nitrate. For example, it appears that under 'optimal' conditions in Oxic+ Nitrate_AQ, where both oxygen and nitrate are present to sustain respiratory activity, the intracellular nitrate pool throughout the $84 \mathrm{~d}$ incubation period was not directly affected, as the measurements were not statistically different ( $p>0.05$, Kruskal-Wallis test) at any point in time. However, it can be argued that the nitrate concentrations in Oxic+Nitrate_AQ did show some decline with time, as only very low concentrations were found at the end of the experiment (Fig. 5). These low nitrate values may be related to the low ATP, or energy, levels (Fig. 3) and potentially low food availability in this treatment. The maintenance of nitrate storage, against the strong environmental gradient, costs the cell energy, and the minimum energy required to concentrate a solute $x$-fold up from ambi-
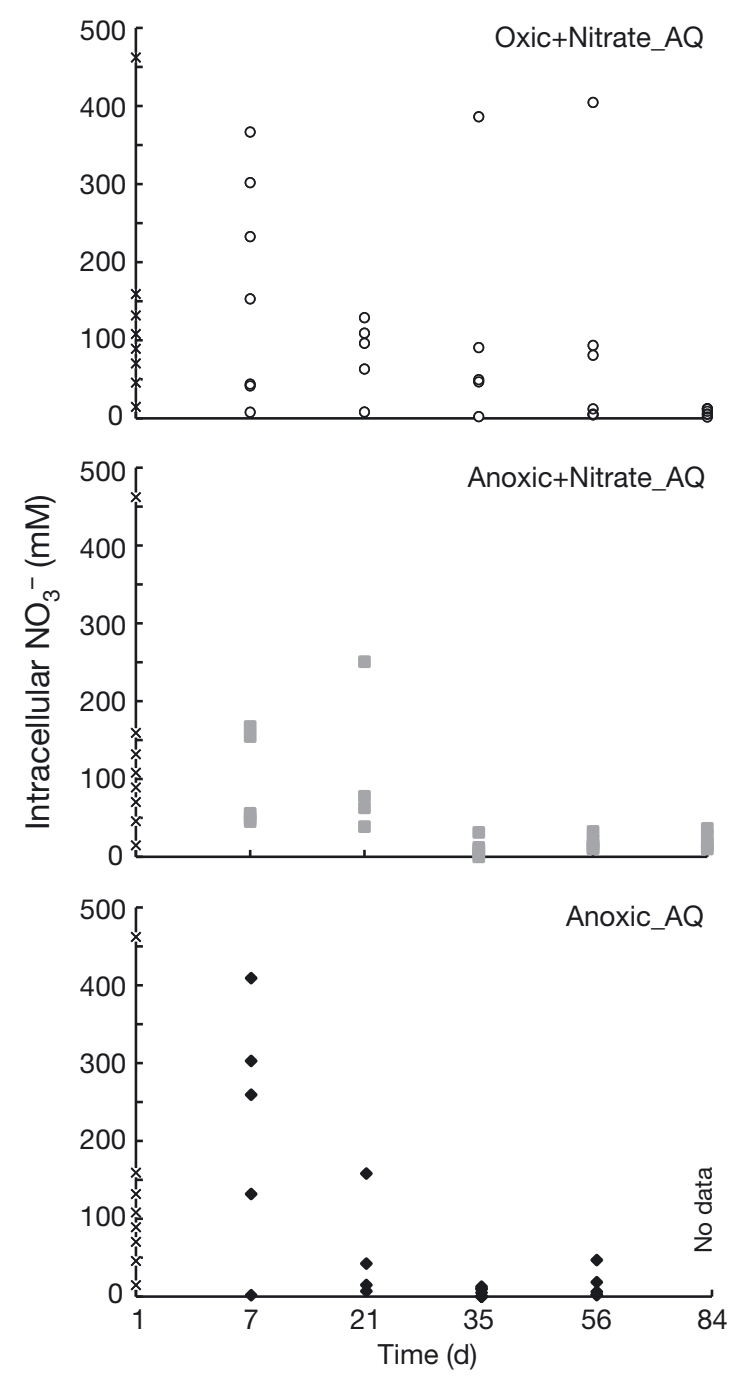

Fig. 5. Globobulimina turgida. Intracellular nitrate pool of foraminiferans versus time for each aquarium. Background measurements of $t=0$ (Day 1 ) are shown on the $y$-axis 
ent concentrations is: $\log _{10}(x) \times 5.7 \mathrm{~kJ} \mathrm{~mol}^{-1}$ (Harold 1986). Thus, the average 6000 -fold-higher intracellular nitrate concentration observed throughout the experiment in G. turgida relative to the ambient levels would cost the cells a minimum of $21.56 \mathrm{KJ}$ of free energy $\mathrm{mol}^{-1}$ of nitrate taken up. If we assume a free energy yield of $-566 \mathrm{~kJ} \mathrm{~mol}^{-1}$ nitrate from denitrification (recalculated after Jørgensen 2000) and subtract 66\% lost in ATP formation (recalculated after Jørgensen 2000 and Spanning et al. 2007), then only about $10 \%$ of the energy gained from respiration is used for nitrate storage. Therefore, it can be speculated that at the end of the experiment due to low food supply, in the Oxic+Nitrate_AQ, foraminifera were either not able to sustain the high cellular nitrate concentrations due to lack of energy reserves, or they simply did not have to because they were respiring on oxygen.

In the Anoxic+Nitrate_AQ and Anoxic_AQ, where foraminifera depended on nitrate respiration, we found statistically significant differences $(p=0.001$, $\mathrm{p}=0.003$; Kruskal-Wallis test) between medians of intracellular nitrate concentration in live Globobulimina turgida in both nitrogen-flushed aquaria (Anoxic+ Nitrate_AQ and Anoxic_AQ) and at different sampling times $(1,7,21,35,56$ and $84 \mathrm{~d})$, especially after 35, 56 and $84 \mathrm{~d}$ in the Anoxic+Nitrate_AQ and 21, 35 and $56 \mathrm{~d}$ in Anoxic_AQ. Furthermore, the intracellular nitrate concentrations were observed to decrease fastest in the Anoxic_AQ where under anoxic and nitrate-free conditions, G. turgida was 'forced' to use its intracellular nitrate without being able to replenish it over time.

\section{Nitrate respiration and intracellular nitrate turnover}

A complete denitrification to $\mathrm{N}_{2}$ gas has been shown to be a mutual ability among the nitrate-storing benthic foraminifera (Risgaard-Petersen et al. 2006, Høgslund et al. 2008, Piña-Ochoa et al. 2010). Our results also confirmed the ability of Globobulimina turgida to respire nitrate to $\mathrm{N}_{2}$, thus validating that the intracellular nitrate pool was used for respiration. Denitrification rates ranged between $263 \pm 8( \pm \mathrm{SE})$ and $453 \pm 30 \mathrm{pmol}$ $\mathrm{N}$ ind..$^{-1} \mathrm{~d}^{-1}$, as derived from Fig. 6 , similar to activity measured previously for G. turgida (565 pmol N ind. ${ }^{-1}$ $\mathrm{d}^{-1}$ ), using ${ }^{15} \mathrm{~N}$-techniques (Risgaard-Petersen et al. 2006). Production of nitrous oxide by G. turgida was also measured in the absence of acetylene, similar to Bolivina plicata, Valvulineria cf. laevigata and Stainforthia sp. from the Peruvian Oxygen Minimum Zone (OMZ, Piña-Ochoa et al. 2010). Nevertheless, the $\mathrm{N}_{2} \mathrm{O}$ production in G. turgida without acetylene was only 27 to $46 \%$ of the rates measured with acetylene, while

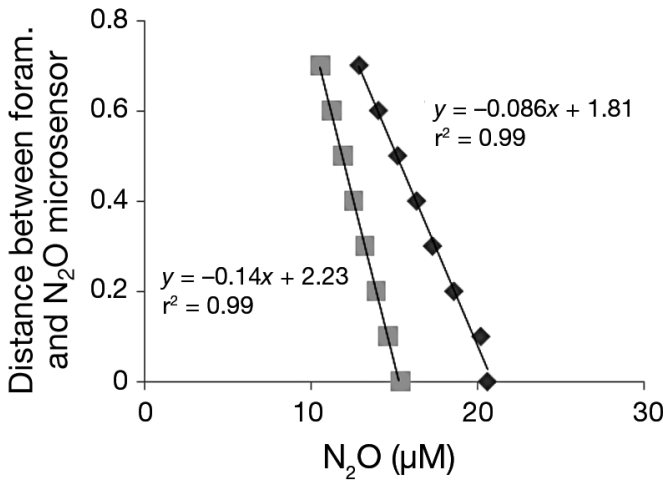

Fig. 6. Globobulimina turgida. Profile of nitrous oxide production in 2 replicate batches of foraminiferans (foram.). Profiles measured in anoxic microtubes using 3 individuals (dark gray symbols) or 2 individuals (light gray symbols)

$\mathrm{N}_{2} \mathrm{O}$ production in the OMZ species was 91 to $95 \%$. Thus, the role of foraminifera as a greenhouse gas source still needs to be assessed.

The intracellular nitrate pool turnover time for Globobulimina turgida was estimated by RisgaardPetersen et al. (2006) to be on the order of $1 \mathrm{mo}$. Based on our denitrification rate of $453 \pm 30$ pmol N ind. ${ }^{-1} \mathrm{~d}^{-1}$ and the maximum cell bound nitrate content $\left(42480\right.$ pmol cell $^{-1}$ ) found in Anoxic_AQ at $t=1$, our results suggest that foraminifera can sustain their respiratory activity for up to 3 mo if using their intracellular nitrate pool only (Fig. 7), or for about $5.5 \mathrm{mo}$ when considering the lower turnover rate of $263 \pm$ 8 pmol $\mathrm{N}$ ind. ${ }^{-1} \mathrm{~d}^{-1}$. However, the maximum cell bound nitrate content is nearly 10 times higher than the average nitrate pool measured in all treatments at all sampling times. Therefore, it seems more likely that on average the nitrate turnover time is on the order of $20 \mathrm{~d}$ (Fig. 7), which is within the estimates of Risgaard-Petersen et al. (2006). Furthermore, this observation is in agreement with our intracellular nitrate pool data for Anoxic_AQ, where the median cell-bound nitrate started clearly declining after the $21 \mathrm{~d}$ incubation period (Fig. 5), and by $35 \mathrm{~d}$ the nitrate pool had become very limited, leading to increased mortality among foraminifera (Fig. 2).

\section{Nitrate respiration strategies: prokaryotes versus eukaryotes}

Traditionally, nitrate respiration is considered mainly a prokaryotic process, and only a few eukaryotic organisms, such as ciliates (Finlay et al. 1983) and fungi (Kobayashi et al. 1996, Takaya et al. 1999, Tielens et al. 2002), have been described as reducing nitrate. However, the discovery of denitrification com- 

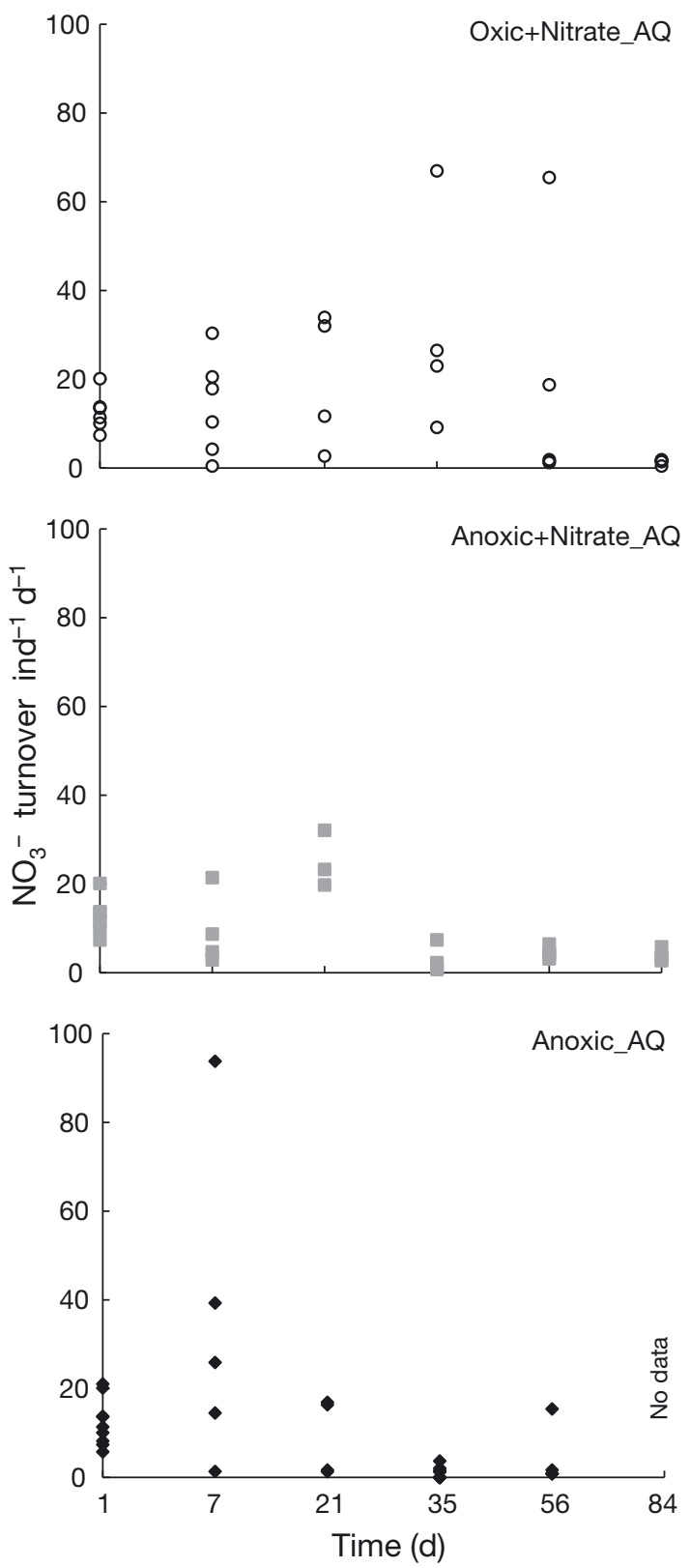

Fig. 7. Globobulimina turgida. Nitrate turnover rates in Oxic+Nitrate_AQ, Anoxic+Nitrate_AQ and Anoxic_AQ based on the denitrification rate of $453 \pm 30 \mathrm{pmol} \mathrm{N}$ ind..$^{-1} \mathrm{~d}^{-1}$

monly occurring among Foraminifera has challenged our understanding of the role of eukaryotes in the nitrogen cycle (Piña-Ochoa et al. 2010). Large differences, however, exist between the nitrate respiration in prokaryotes, ciliates, fungi and foraminifera. Firstly, where ciliates (Loxodes spp., Finlay et al. 1983) and fungi (e.g. Fusarium oxysporum and Cylindrocarpon tonkinese, Tielens et al. 2002) are capable of reducing nitrate only to nitrite, foraminifera can perform complete denitrification with $\mathrm{N}_{2}$ as the end product of res- piration. Further, foraminifera are able to reduce nitrate in the absence of oxygen/nitrate and move to areas where there is no measurable oxygen/nitrate. In contrast, sessile fungi only switch to nitrate reduction when oxygen concentrations become limiting (Takaya et al. 1999).

It seems that the nitrate-accumulating and -respiring foraminifera share some life strategies with other nitrate-storing prokaryotes, such as 3 genera of sulphur bacteria (Beggiatoa, Thioploca and Thiomargarita) that frequently dominate nitrate rich and oxygen-depleted sediments of the seafloor (Fossing et al. 1995, McHatton et al. 1996, Schulz et al. 1999). For instance, large sulphur bacteria, such as Thioploca and Beggiatoa, are able to store nitrate in vacuoles and carry it deep into oxygen- and nitrate-free environments by migration, which, similar to foraminifera, enables the organisms to sustain nitrate respiration in a nitrate-free environment (Høgslund et al. 2009). The migration behaviour between redox zones is also commonly observed among foraminifera (e.g. Geslin et al. 2004, Pucci et al. 2009), and thus it is very likely that this behaviour is closely linked to the nitrate uptake, or nitrate refuelling, and respiration of stored nitrate. A major difference between foraminifera and nitratestoring sulphur bacteria, however, is the end product of nitrate respiration. While the preferred respiratory pathway of bacteria is dissimilatory reduction of nitrate to ammonium (Otte et al. 1999), foraminifera reduce intracellular nitrate to dinitrogen gas.

\section{CONCLUSIONS}

In our laboratory experiments, we observed that the benthic foraminiferan Globobulimina turgida is capable of long-term survival under simulated anoxic conditions if nitrate is readily available to sustain cellular respiration. In the absence of desired electron acceptors (oxygen and nitrate), the survival rates of $G$. turgida are reduced. Nevertheless, G. turgida can survive up to $56 \mathrm{~d}$ if respiring the intracellular nitrate pool only. Therefore, the capacity of G. turgida to respire on oxygen and nitrate, and its relatively long-term survival through use of the intracellular nitrate pool, allows the foraminiferan to reside in a wide range of sediment depths and to inhabit various sediment redox zones. Our results also showed similar ATP concentrations in specimens incubated under different oxygen/ nitrate conditions, indicating that in the long term, the metabolic activity of G. turgida remained the same in both environments.

The capacity of Globobulimina turgida to denitrify nitrate to $\mathrm{N}_{2}$ gas was confirmed. The rates varied between $263 \pm 8( \pm \mathrm{SE})$ and $453 \pm 30 \mathrm{pmol} \mathrm{N}$ ind.$^{-1} \mathrm{~d}^{-1}$. 
The production of $\mathrm{N}_{2} \mathrm{O}$ was also measured in the absence of acetylene; however, the production was only 27 to $46 \%$ of the rates measured with acetylene. Clearly, further observational and experimental data are required to clarify the relevance of foraminifera as a potential greenhouse gas source and their role in the $\mathrm{N}$ cycle.

Acknowledgements. We thank N. P. Revsbech for designing the chambers for denitrification measurements, P. Sørensen for providing microsensors, the crew of RV 'Oscar von Sydow' at the Kristineberg Marine Field station (Sweden) and P. Linke and A. Scheltz at Kiel University for providing advice on ATP measurements. We acknowledge the comments of 3 anonymous reviewers (especially reviewer no. 3), which improved an earlier version of the manuscript. This research was financially supported by the European Union Marie Curie Fellowship (FP7-IEF-220894), the Netherlands Organisation for Scientific Research (NWO), Darwin Center for Biogeosciences (grant no. 1092), Danish National Research Foundation and the German Max Plank Society.

\section{LITERATURE CITED}

Alberts B, Bray D, Johnson A, Lewis J, Raff M, Roberts K, Walter P (1998) Essential cell biology: an introduction to the molecular biology of the cell. Garland Publishing, New York, NY

Andersen K, Kjar T, Revsbech NP (2001) An oxygen insensitive microsensor for nitrous oxide. Sens Actuators B Chem 81:42-48

Bender ML, Heggie DT (1984) Fate of organic carbon reaching the deep sea floor: a status report. Geochim Cosmochim Acta 48:977-986

Bernhard JM (1993) Experimental and field evidence of Antarctic foraminiferal tolerance to anoxia and hydrogen sulfide. Mar Micropaleontol 20:203-213

Bernhard JM, Alve E (1996) Survival, ATP pool, and ultrastructural characterization of benthic foraminifera from Drammensfjord (Norway): response to anoxia. Mar Micropaleontol 28:5-17

Bernhard JM, Reimers CE (1991) Benthic foraminiferal population fluctuations related to anoxia: Santa Barbara Basin. Biogeochemistry 15:127-149

Bernhard JM, Newkirk SG, Bowser SS (1995) Towards a nonterminal viability assay for foraminiferan protists. J Eukaryot Microbiol 42:357-367

Braman RS, Hendrix SA (1989) Nanogram nitrite and nitrate determination in environmental and biological materials by vanadium(III) reduction with chemiluminescence detection. Anal Chem 61:2715-2718

Engström P, Dalsgaard T, Hulth S, Aller RC (2005) Anaerobic ammonium oxidation by nitrite (anammox): implications for $\mathrm{N}_{2}$ production in coastal marine sediments. Geochim Cosmochim Acta 69:2057-2065

Filipsson HL, Nordberg K, Gustafsson M (2004) Seasonal study of $\delta^{18} \mathrm{O}$ and $\delta^{13} \mathrm{C}$ in living (stained) benthic foraminifera from two Swedish fjords. Mar Micropaleontol 53: $159-172$

> Finlay BJ, Span ASW, Harman JMP (1983) Nitrate respiration in primitive eukaryotes. Nature 303:333-336

Fontanier C, Jorissen FJ, Chailloua G, David C, Anschutz P, Lafon V (2003) Seasonal and interannual variability of benthic foraminiferal faunas at $550 \mathrm{~m}$ depth in the Bay of Biscay. Deep-Sea Res I 50:457-494

Fossing H, Gallardo VA, Jorgensen BB, Huttel M and others (1995) Concentration and transport of nitrate by the matforming sulphur bacterium Thioploca. Nature 374: $713-715$

Geslin E, Heinz P, Jorissen F, Hemleben C (2004) Migratory responses of deep-sea benthic foraminifera to variable oxygen conditions: laboratory investigations. Mar Micropaleontol 53:227-243

Glud RN, Thamdrup B, Stahl H, Wenzhoefer F and others (2009) Nitrogen cycling in a deep ocean margin sediment (Sagami Bay, Japan). Limnol Oceanogr 54:723-734

Graf G, Linke P (1992) Adenosine nucleotides as indicators of deep-sea benthic metabolism. In: Rowe GT, Pariente V (eds) Deep-sea food chains and the global carbon cycle. NATO ASI Ser C, Vol 360. Kluwer Academic Publishers, Dordrecht, p 237-243

Harold FM (1986) The vital force: a study of bioenergetics. W. H. Freeman, New York, NY

> Høgslund S, Revsbech NP, Cedhagen T, Nielsen LP, Gallardo VA (2008) Denitrification, nitrate turnover, and aerobic respiration by benthic foraminiferans in the oxygen minimum zone off Chile. J Exp Mar Biol Ecol 359:85-91

> Høgslund S, Revsbech NP, Kuenen JG, Jørgensen BB and others (2009) Physiology and behaviour of marine Thioploca. ISME J 3:647-657

Irabien MJ, Cearreta A, Leorri E, Gómez J, Viguri J (2008) A 130 year record of pollution in the Suances estuary (southern Bay of Biscay): implications for environmental management. Mar Pollut Bull 56:1719-1727

Jørgensen BB (2000). Bacteria and marine biogeochemistry. In: Schulz HD, Zabel M (eds) Marine geochemistry. Springer, Berlin, p 173-207

Jorissen FJ, De Stigter HC, Widmark JGV (1995) A conceptual model explaining benthic foraminiferal microhabitats. Mar Micropaleontol 26:3-15

Jorissen FJ, Fontanier C, Thomas E (2007) Paleoceanographical proxies based on deep-sea benthic foraminiferal assemblage characteristics. Dev Mar Geol 1:263-325

Kitazato H, Shirayama Y, Nakatsuka T, Fujiwara S and others (2000) Seasonal phytodetritus deposition and responses of bathyal benthic foraminiferal populations in Sagami Bay, Japan: preliminary results from 'Project Sagami 1996-1999'. Mar Micropaleontol 40:135-149

Kobayashi M, Matsuo Y, Takimoto A, Suzuki S, Maruo F, Shoun H (1996) Denitrification, a novel type of respiratory metabolism in fungal mitochondrion. J Biol Chem 271: 16263-16267

Koho KA, García R, de Stigter HC, Epping E, Koning E, Kouwenhoven TJ, van der Zwaan GJ (2008a) Sedimentary labile organic carbon and pore water redox control on species distribution of benthic foraminifera: a case study from Lisbon-Setúbal Canyon (southern Portugal). Prog Oceanogr 79:55-82

Koho KA, Langezaal AM, van Lith YA, Duijnstee IAP, van der Zwaan GJ (2008b) The influence of a simulated diatom bloom on deep-sea benthic foraminifera and the activity of bacteria: a mesocosm study. Deep-Sea Res I 55:696-719

Linke P (1992) Metabolic adaptations of deep-sea benthic foraminifera to seasonally varying food input. Mar Ecol Prog Ser 81:51-63

McHatton SC, Barry JP, Jannasch HW, Nelson DC (1996) High nitrate concentrations in vacuolate, autotrophic marine Beggiatoa spp. Appl Environ Microbiol 62:954-958

> Mojtahid M, Jorissen F, Pearson TH (2008) Comparison of benthic foraminiferal and macrofaunal responses to 
organic pollution in the Firth of Clyde (Scotland). Mar Pollut Bull 56:42-76

Moodley L, van der Zwaan GJ, Herman PMJ, Kempers L, van Breugel P (1997) Differential response of benthic meiofauna to anoxia with special reference to Foraminifera (Protista: Sarcodina). Mar Ecol Prog Ser 158:151-163

Moodley L, Schaub BEM, Van Der Zwaan GJ, Herman PMJ (1998) Tolerance of benthic foraminifera (Protista: Sarcodina) to hydrogen sulphide. Mar Ecol Prog Ser 169:77-86

Nordberg K, Gustafsson M, Krantz A (2000) Decreasing oxygen concentrations in the Gullmar Fjord, Sweden, as confirmed by benthic foraminifera, and the possible association with NAO. J Mar Syst 23:303-316

Otte S, Kuenen JG, Nielsen LP, Paerl HW and others (1999) Nitrogen, carbon, and sulfur metabolism in natural Thioploca samples. Appl Environ Microbiol 65:3148-3157

Piña-Ochoa E, Høgslund S, Geslin E, Cedhagen T and others (2010) Widespread occurrence of nitrate storage and denitrification among Foraminifera and Gromiida. Proc Natl Acad Sci USA 107:1148-1153

Pucci F, Geslin E, Barras C, Morigi C, Sabbatini A, Negri A (2009) Survival of benthic foraminifera under hypoxic conditions: results of an experimental study using the Cell Tracker Green method. Mar Pollut Bull 59:336-351

Revsbech NP (1989) An oxygen microsensor with a guard cathode. Limnol Oceanogr 34:474-478

Risgaard-Petersen N, Langezaal AM, Ingvardsen S, Schmid MC and others (2006) Evidence for complete denitrification in a benthic foraminifer. Nature 443:93-96

Sayama M (2001) Presence of nitrate-accumulating sulfur

Editorial responsibility: Hans Heinrich Janssen,

Oldendorf/Luhe, Germany bacteria and their influence on nitrogen cycling in a shallow coastal marine sediment. Appl Environ Microbiol 67: 3481-3487

Schulz HN, Brinkhoff T, Ferdelman TG, Hernández Mariné M, Teske A, Jørgensen BB (1999) Dense populations of a giant sulfur bacterium in Namibian shelf sediments. Science 284:493-495

Smith MS, Firestone MK, Tiedje JM (1978) The acetylene inhibition method for short-term measurement of soil denitrification and its evaluation using nitrogen-13. Soil Sci Soc Am J 42:611-615

Spanning RJM, Richardson DJ, Ferguson SJ (2007). Introduction to the biochemistry and molecular biology of denitrification. In: Bothe H, Ferguson SJ, Newton WE (eds) Biology of the nitrogen cycle. Elsevier, Amsterdam, p 3-20

> Takaya N, Suzuki S, Kuwazaki S, Shoun H, Maruo F, Yamaguchi M, Takeo K (1999) Cytochrome P450nor, a novel class of mitochondrial cytochrome P450 involved in nitrate respiration in the fungus Fusarium oxysporum. Arch Biochem Biophys 372:340-346

Tielens AGM, Rotte C, Van Hellemond JJ, Martin W (2002) Mitochondria as we don't know them. Trends Biochem Sci 27:564-572

Van Der Zwaan GJ, Duijnstee IAP, Den Dulk M, Ernst SR, Jannink NT, Kouwenhoven TJ (1999) Benthic foraminifers: proxies or problems? A review of paleocological concepts. Earth Sci Rev 46:213-236

Witzel K (1979) The adenylate energy charge as a measure of microbial activities in aquatic habitats. Archiv für Hydrobiologie, Beiheft, 12:146-165

Submitted: May 19, 2010; Accepted: September 2, 2010

Proofs received from author(s): October 29, 2010 